Vandecasteele B., Samyn J., Quataert P., Muys B., Tack F.M.G., 2004. Earthworm biomass as additional information for risk assessment of heavy metal biomagnification: a case study for dredged sediment-derived soils and polluted floodplain soils. Environmental Pollution 129 (3), 363-375.

The original publication is available at http://www.elsevier.com/

\title{
Earthworm biomass as additional information for risk assessment of heavy metal biomagnification: a case study for dredged sediment-derived soils and polluted floodplain soils.
}

\author{
BART VANDECASTEELE, ${ }^{\mathrm{a}, *}$, JURGEN SAMYNa, PAUL QUATAERT ${ }^{\mathrm{a}}$, BART \\ MUYS ${ }^{\mathrm{b}}$, FILIP M.G. TACK
}

anstitute for Forestry and Game Management, Ministry of the Flemish Community,

Gaverstraat 4, B-9500 Geraardsbergen, Belgium

${ }^{\mathrm{b}}$ Katholieke Universiteit Leuven, Laboratory for Forest, Nature and Landscape Research,

Vital Decosterstraat 102, B-3000 Leuven, Belgium

${ }^{\mathrm{c}}$ Ghent University, Department of Applied Analytical and Physical Chemistry, Coupure 653, B-9000 Ghent, Belgium

* Correspondence: B. Vandecasteele. E-mail: Bart.Vandecasteele@lin.vlaanderen.be, Tel. + 3254 437136, Fax. + 3254436160 


\section{Abstract}

The importance of earthworms for heavy metal biomagnification in terrestrial ecosystems is widely recognised. Differences in earthworm biomass between sites is mostly not accounted for in ecological risk assessment. These differences may be large depending on soil properties and pollution status. A survey of earthworm biomass and colonisation rate was carried out on dredged sediment-derived soils (DSDS). Results were compared with observations for the surrounding alluvial plains. Mainly grain size distribution and time since disposal determined earthworm biomass on DSDS, while soil pollution status of the DSDS was of lesser importance. Highest earthworm biomass was observed on sandy loam DSDS disposed at least 40 years ago.

Keywords: landfills, earthworms, alluvial, risk, colonisation

Capsule: Polluted clayey dredged sediment-derived soils have a relatively low risk for heavy metal biomagnification due to slow earthworm colonisation.

\section{Introduction}

Metals may enter the food web via soil dwelling organisms living on dredged sediment-derived soils (DSDS) and contaminated floodplains. Earthworms constitute the largest terrestrial faunal biomass. In the transfer of pollutants towards other trophic levels, they occupy a key position (Kreis et al., 1987, Granval and Aliaga, 1988). Earthworms were found to have a high potential for $\mathrm{Cd}$ accumulation in polluted floodplains (Hendriks et al., 1995). They have been considered useful for assessing heavy metal pollution in soils (Menzie et al., 1992) because earthworm biomass and abundance were found to be more sensitive to pollution in comparison with other indicator taxa (Spurgeon et al., 1996). The presence and abundance of earthworms can be a determining factor for the occurrence of higher organisms. Presence of Little Owl (Athene noctua) in Flanders could be predicted based on landscape and soil characteristics. The highest occurrence of Little Owl was on locations with soils optimal for large earthworm populations (Van Nieuwenhuyse et al., 2001).

Heavy metal pollution can induce two major effects on the ecosystem level: (a) accumulation of e.g. Cd can lead to risks of secondary poisoning, while (b) earthworms disappear already at low levels of soil $\mathrm{Cu}$ which can cause food scarcity for earthworm predators (Abdul Rida, 1992; Klok et al., 2000).

A major factor for both heavy metal uptake and toxicity (Ma et al., 1983), and earthworm abundance (Muys and Lust, 1992) is the soil $\mathrm{pH}$. The $\mathrm{pH}$ of the soil material decreases during gut passage in L. terrestris Linnaeus (Heine and Larink, 1993). Brzóska and Moniuszko-Jakoniuk (1998) found a strong interaction between $\mathrm{Cd}$ and $\mathrm{Ca}$ in feed, resulting in a lower toxicity of $\mathrm{Cd}$ at high $\mathrm{Ca}$ intakes. Earthworms are very sensitive to $\mathrm{Cu}(\mathrm{Ma}, 1982$; Ma et al., 1983), but $\mathrm{Cu}$ accumulation by earthworms is particularly unpredictable (Edwards et al., 1998). Besides $\mathrm{pH}$, soil characteristics like OM content and CEC are influencing heavy metal availability and uptake by L. rubellus Hoffmeister (Ma, 1982; Ma et al., 1983). Beyer et al. (1990) presumed that the acidity ( $\mathrm{pH} 3.0-5.5)$ of the dredged sediment substrate at four confined disposal facilities was responsible for the absence of earthworms, as on an older landfill with a higher $\mathrm{pH}$, earthworms were found. 
Modelling of uptake kinetics and accumulation of heavy metals by earthworms as a biological reference system and as a key process in trophic transfer for risk assessment on polluted sites is a current topic (Abdul Rida, 1992; Beyer and Stafford, 1993; Kooistra et al., 2001). In situ observation of biomass and population dynamics of earthworms can be a means to determine long term effects. The importance of earthworms for heavy metal biomagnification in terrestrial ecosystems is widely recognised. Knowledge of earthworm heavy metal tissue concentrations is essential for risk assessment of heavy metal biomagnification. Large differences in earthworm biomass may be encountered on different locations as a function of soil properties and soil pollution status, or due to colonisation/recolonisation. Despite this, earthworm biomass is mostly not incorporated in site-specific ecological risk assessment and homogeneous earthworm biomass is usually assumed.

To allow for risk assessment on DSDS and floodplains affected by overbank sedimentation, we will focus in this paper on earthworm biomass and population dynamics relative to the surrounding unaffected alluvial plains. The pollution level of the floodplain soils and several characteristics of the DSDS (time since disposal, pollution level, physicochemical properties) will be included in the analysis. The originality of this study lies in the fact that the studied DSDS were new soils at the time of disposal and are expected to be slowly invaded by earthworms. We feel that most research about earthworm populations in polluted areas focuses on superficially located pollution, concentrated in the upper $\mathrm{cm}$ of the soil profile. This is the case for forests around smelters (Bengtsson and Tranvik, 1989, Martin and Bullock, 1994), floodplain soils (Hendriks et al., 1995; Ma et al., 1997), areas polluted by agricultural activities (Ma, 1988; Filser et al., 1995; Didden, 2001), or by use of timber preservatives (Yeates and Orchard, 1994). All these case studies have in common that a developed soil profile has gradually been polluted from the top layer, existing earthworm populations were subjected to an increasing environmental stress and consequently, earthworm population changes might be measured. In such locations, soil pollution is relatively heterogeneous and organisms can survive through avoidance (Eijsacker, 1987; Ma, 1988; Yeates and Orchard, 1994).

In the DSDS studied here, the polluted soil profile is established at once over a larger thickness ( $>80 \mathrm{~cm}$ at least in this study). The reduced sediment was hydraulically pumped on the site and caused the earthworms from the original soil to disappear (Fig. 1). During development of the sediment layer, subsoil is not a cleaner refuge for earthworms. Suter et al. (2000) stress the importance of selecting adequate reference locations for soil biological surveys since high variation in quantities of soil biota from location to location were regularly observed. We will make an attempt to link earthworm biomass and density with ecological and pollution factors and use these data for a general risk assessment.

\section{Materials and methods}

\subsection{Study area}

All sampling plots in this paper were located along the Scheldt and Leie river and the Canal Ghent-Bruges (Fig. 2). The presented study was executed in two steps. In a first exploratory step, total biomass and density of earthworms, and the relative distribution over the ecological categories were compared for three unaffected alluvial soils (ALL), four alluvial soils polluted due to overbank sedimentation (overbank sedimentation zones $=$ OSZ) and five soils affected by dredged sediment disposal (dredged sediment-derived soils = DSDS) (Table 1, Table 2). Plots were selected to allow for pair-wise comparison of sites of a 
different soil type located close to each other. In the second step, the influence of soil physical conditions, pollution status and general landfill characteristics on the biomass and density of earthworms on 19 DSDS (Table 3, Table 4) was determined. Five of the 19 sites were already sampled for the research goal of step 1. All sampled alluvial soils were under pasture, while the sampled DSDS were used for pasture or forestry, or developed as brushwood.

\subsection{Earthworm and soil sampling}

The ecological categories of earthworms could be distinguished functionally or evolutively (Bouché, 1972; Muys and Lust, 1992). Functionally, three groups are distinguished: epigeic, endogeic and anecic earthworms. The epigeic earthworms live in compost or in litter, and are adapted through more expressed pigmentation. The litter forms their food and the function of this group is to fragment and digest the soil organic matter. The endogeic earthworms burrow horizontal galleries into soils rich in humus. This group consists of humus feeders which are not involved in the litter decomposition, but it is an important group for the bioturbation of the upper $30 \mathrm{~cm}$ of the soil. The anecic earthworms burrow vertical galleries in the soil and take up food at the soil surface, especially at night.

Earthworm sampling was done on all sites with six replicates between September and November 2001 (13 sites), in April 2002 (2 sites) and between September and November 2002 (11 sites) according to the combined method of Bouché and Aliaga (1986). At the time of sampling, soil moisture content was at field capacity, and differences in soil moisture conditions between sites can be addressed to soil type and hydrological conditions of the sites. When selecting the sampled sites for the DSDS, care was taken to stay at least $15 \mathrm{~m}$ from the landfill edge to exclude fast migration of earthworms as a confounding factor influencing the biomass. As no litter layer was found on any site, sampling of the litter layer was unnecessary. Sprinkling the two nested subplots $\left(0.5 \mathrm{~m}^{2}\right.$ each) with formalin solutions $(2$ times $10 \mathrm{~L}$ of a $0.05 \%$ solution and 2 times $10 \mathrm{~L}$ of a $0.1 \%$ solution at 10 minute intervals) yielded the first earthworm fraction. The second fraction was obtained after wet washing and sieving $20 \mathrm{dm}^{3}$ of a soil sample $\left(0.1 \mathrm{~m}^{2}\right)$ from every subplot after pretreatment during $48 \mathrm{~h}$ in a solution of 10 $\mathrm{L}$ water, $100 \mathrm{~mL}$ sodium hexametaphosphate and $800 \mathrm{~mL}$ formalin. Both earthworms from formalin application and wet soil sieving were preserved in a $37 \%$ formalin solution. Formalin extraction and formalin conservation caused irritation and intense movements resulting in a certain defaecation. Within a week after sampling, total earthworm biomass and density was determined after drying for $1 \mathrm{~min}$ on a filter paper at room temperature. Collected earthworms from all fractions were identified, counted and weighed. Calculation of the fresh earthworm biomass in $\mathrm{g} / \mathrm{m}^{2}$ was done by:

[( mass earthworms soil *2) + (mass earthworms soil after sieving * 10)]

Juveniles, parts of earthworms and non-identifiable species were pro rata attributed to species. To reduce the time-consuming species identification step, we limited species identification to a number of replicates until at least $40 \mathrm{~g}$ of field-collected fresh weight (FW) was determined. For sites with less fresh material, all subsamples were used. Earthworm biomass per ecological category (Bouché, 1972) was calculated for a general description of the data.

After the first sampling on DSDS (step 1), it was concluded that additional soil core sampling after formalin extraction did not result in additional information about species diversity or ecological categories. Only a low biomass gain ( at most $16 \%$ ) was obtained by additional soil core sampling. Furthermore the soil sampling, transportation, dispersion and sieving is a very time-consuming step with an important impact on the sampled area. For this 
reason, the determination of the relation between soil characteristics and earthworm populations on DSDS (step 2) was based on formalin extraction data only. Data for both formalin extraction and soil sampling were available for APV1 and APV8.

Before earthworm sampling started, soil samples $(0-20 \mathrm{~cm}$ horizon) for separate chemical analysis were collected outside the sampling frame, on a distance of $20 \mathrm{~cm}$. The methods used for chemical soil analysis are described in Vandecasteele et al. (2003). Soil total contents of $\mathrm{Cd}, \mathrm{Cr}, \mathrm{Cu}, \mathrm{Ni}, \mathrm{Pb}, \mathrm{S}, \mathrm{P}$ and $\mathrm{Zn}$ are actually pseudo-total aqua regia extractable contents measured with ICP-AES after microwave digestion. Soil physical properties on the DSDS were estimated based on measurement of soil bulk density, penetration resistance and saturated hydraulic conductivity (Ksat) and calculation of the ripening factor. On each DSDS, four core samples of $100 \mathrm{~cm}^{3}$ were taken at the soil surface and used for determination of saturated hydraulic conductivity with an ICW permeameter (Eijkelkamp Agrisearch Equipment, Giesbeek, The Netherlands) and bulk density calculation (ISO 11272). At four points per DSDS, penetration resistance was measured when soil was at field capacity using an Eijkelkamp penetrometer (Eijkelkamp Agrisearch Equipment, Giesbeek, The Netherlands), capable of recording values at intervals of $1 \mathrm{~cm}$ to a depth of $80 \mathrm{~cm}$. A $1 \mathrm{~cm}^{2}$ base area cone was used with an angle of $60^{\circ}$. The penetration in the soil occurred at a rate of $20 \pm 5 \mathrm{~mm} / \mathrm{s}$. For the measurements of the penetration resistance, the maximum values for the $0-40 \mathrm{~cm}$ (measurements in $1 \mathrm{~cm}$ intervals) layer for the four replicates was used as value for the site. For bulk density and permeability, average resp. median values for the four replicates were used. For all soil samples on DSDS, the ripening factor as used by de Haan et al. (1998) was calculated as a measure of the ripening rate.

Ripening factor $=[\mathrm{A}-\mathrm{p} *(100-\mathrm{L}-\mathrm{H})] /[\mathrm{L}+\mathrm{b} * \mathrm{H}]$ with:

A: water percentage (g/100 g DM)

$\mathrm{H}$ : organic matter percentage $(\mathrm{g} / 100 \mathrm{~g} \mathrm{DM})$

$\mathrm{L}$ : clay fraction $(\mathrm{g} / 100 \mathrm{~g} \mathrm{DM})$

b: ratio between water absorption capacity of organic matter and absorption capacity of clay (usually $b=3$ )

$\mathrm{p}$ : moisture bound by non-colloidal material (usually $\mathrm{p}=0.2 \mathrm{~g} / 100 \mathrm{~g}$ non-colloidal material)

\subsection{Data handling and statistics}

All earthworm biomass data were expressed on a fresh weight base $\left(\mathrm{g} / \mathrm{m}^{2} \mathrm{FW}\right)$. As individual earthworm weight varied between $<0.01 \mathrm{~g} \mathrm{FW}$ and $>4 \mathrm{~g} \mathrm{FW}$ for the sampled species, earthworm biomass rather than earthworm density was chosen to represent food availability for predators. For two replicates on the APV8 site, earthworm biomass was very low. The reason for this observation was unknown but the site was recently affected by tree cutting, which probably caused soil compaction. For the RVD1 site, two replicates were situated on soils with deviant soil properties relative to the other four replicates. For these two sites, deviant replicates were excluded from further analysis.

The three soil categories (ALL, OSZ and DSDS) were compared for soil properties and earthworm parameters with oneway ANOVA after grouped variables were tested for normality and homoscedasticity. Variables included in the analysis were earthworm biomass (expressed as $\mathrm{g} \mathrm{FW} / \mathrm{m}^{2}$ ) and density (expressed as $\mathrm{N} / \mathrm{m}^{2}$ ), soil pollution status $(\mathrm{Cr}, \mathrm{Cu}, \mathrm{Cd}, \mathrm{Pb}$ and $\mathrm{Zn}$ ) and soil properties (gravimetric dry matter content (DM), TOC, $\mathrm{pH}$, total $\mathrm{S}$, total $\mathrm{P}$, 
$\mathrm{CaCO}_{3}, \mathrm{~N}$, grain size distribution). Data for $\mathrm{CaCO}_{3}, \mathrm{Cd}, \mathrm{Cr}, \mathrm{Zn}, \mathrm{Cu}$ were log-transformed prior to ANOVA. Additionally, the heaviest adult L. rubellus was recorded as a measure of the appropriateness of sites for earthworms.

A linear model was built for interpretation of DSDS earthworm biomass as a function of soil properties. To test which factors have an impact and to assess their magnitude a multivariate regression model was built in two steps. First, a reference model was constructed with the factors, grain size and time since disposal (TSD), because these two variables were recognised a priori as dominant during exploratory data analysis. The very question was if on top of this basic model other additional factors were important. For this second step first the residuals of the reference model were checked visually for patterns against the other soil variables and pollution status. Next, a stepwise regression searched for the best subset of variables at a significance level of 0.05 . For this model only the final result is shown here. Full details of the model are given in the 'results'-section. During statistical model building, both RVD1 and RAE2 sites were observed to be outliers. Data on biomass were square roottransformed before statistical analysis.

\section{Results}

\subsection{Comparison between DSDS and surrounding alluvial soils}

Unaffected alluvial soils (ALL), dredged-sediment derived soils (DSDS) and overbank sedimentation zones (OSZ) did not significantly differ in grain size distribution (clay, silt, sand), EC and soil organic matter content (SOM) (Table 1, results for silt and sand not shown). Gravimetric water content was significantly $(\mathrm{p}<0.001)$ higher for OSZ, while values for DSDS and ALL were comparable. P concentrations in DSDS were higher than in OSZ and ALL $(p<0.001) . P b$ concentrations were higher in DSDS and OSZ compared with ALL $(p<$ $0.001)$. For $\mathrm{CaCO}_{3}(\mathrm{p}<0.0001), \mathrm{Cd}(\mathrm{p}=0.0009), \mathrm{Cu}(\mathrm{p}<0.0001), \mathrm{Zn}(\mathrm{p}<0.0001), \mathrm{Cr}(\mathrm{p}=$ $0.0003)$ and $\mathrm{S}(\mathrm{p}<0.0001)$, concentrations in DSDS were significantly higher than for OSZ, which in turn were significantly higher than for ALL (Table 2). For earthworm density, only a significant difference was found between ALL and OSZ $(p=0.032)$. However, for earthworm biomass, values for ALL were significantly higher $(\mathrm{p}<0.0001)$ than values for both DSDS and OSZ (Table 1). In conclusion, general soil characteristics between the three soil types are similar, but chemical properties of both DSDS and OSZ deviate from the ALL characteristics.

Biomass of earthworms for the selected pairs of sites is shown in Fig. 3a. Biomass is highest for unaffected alluvial soils, intermediate for polluted floodplains and low for the DSDS. Standard deviation (SD) on six replicates is for most sites considerable. When results on density of earthworms is displayed (Fig. 3b), differences between the sites are less clear, but most DSDS are characterised by low densities.

Biomass distribution over the ecological categories is shown in Fig. 4a. It is obvious that on the DSDS endogeic and anecic earthworms are low in biomass or are absent. Relative to the unpolluted alluvial soils, polluted floodplain soils have a higher endogeic biomass. The highest weight recorded for an adult Lumbricus rubellus is displayed in Fig. 4b. For DSDS, the values tended to be lower than for the ALL or OSZ soils, but the difference was not significant $(\mathrm{p}>0.05)$. 


\subsection{Influence of time since disposal and DSDS properties on earthworm populations}

RVD1 and RAE2 were recognised as outliers for earthworm biomass. RAE2 is a recent DSDS where hardly any earthworms were found, while RVD1 was landfilled 25 years ago with strongly contaminated dredged sediments, especially with $\mathrm{Cu}$ and $\mathrm{Zn}$ (Table 4). The RVD1 site was clearly observed to be an outlier based on the PCA of soil data for the sampled DSDS (data not shown). Highest earthworm biomass was observed at the slightly polluted APV8 site and SDD3 site, both with a sandy loam soil, and the APV1 site with a heavy clay soil (Table 3). For the APV8 and APV1 sites, soil cores also were excavated and hand-sorted after washing. Total earthworm biomass was $152 \mathrm{~g} / \mathrm{m}^{2} \mathrm{FW}$ for APV8 and $80 \mathrm{~g} / \mathrm{m}^{2} \mathrm{FW}$ for APV1. Highest biomass recorded at the alluvial soils was $158 \mathrm{~g} / \mathrm{m}^{2} \mathrm{FW}$.

In DSDS a large range in metal concentrations was observed. Total contents of different metals were strongly correlated. From the selected soil physical measurements and calculations, the ripening factor allowed for the clearest distinction between sites. Lowest values were found for the sandy loam DSDS, while the heavy clay sites were split up in sites with values lower than 0.7 ('completely ripened' according to de Haan et al. (1998)) and values between 0.7 and 1.0 ('nearly ripened' according to de Haan et al. (1998)). Values for bulk density and penetration resistance were highest for the sandy loam DSDS. Penetration resistance increased with depth. Averaged results per site were comparable with data for sediment-derived soils in Illinois (Darmody and Marlin, 2002). Measured penetration resistance was clearly lower than values measured by Muys (1993) for compacted forest soils where lower earthworm biomass was observed. The Ksat values for most sites were low compared to data for storm water facilities (Massman and Butchart, 2000) and for dredged sediment disposal sites (Van Driel and Nijssen, 1988). Only for the heavy clay DSDS LMM2, BEL1, GTH9 and RAE2 and the sandy loam KDG4 and SDD3 site, Ksat values were normal to high. For the other sandy loam DSDS, Ksat values were low.

When the relative importance of the ecological categories was displayed as a function of the TSD for both grain size subsets (Fig. 5), it is concluded that epigeic earthworms dominate during the first period of 30 (sandy loam soils) or 40 (heavy clay soils) years. For AKM2, in one replicate one heavy L. terrestris was found, strongly influencing the results when L. terrestris was classified as an anecic species. However, the species is generally described as an epi-anecic species.

The highest negative correlation was found between the highest weight recorded for an adult $L$. rubellus and clay content. Linear regression yielded the equation weight $($ L. rubellus $)$ $=2.63-0.051 * \%$ clay $\left(\mathrm{R}^{2}=0.568, \mathrm{p}=0.0003\right)$.

A linear model was built for interpretation of DSDS earthworm biomass as a function of soil properties. Based on visual interpretation of scatterplots, both grain size distribution and TSD were recognised as main determining factors. Three classes were defined based on the grain size and the ripening factor: average biomass was $13.2,25.7$ and $68.5 \mathrm{~g} \mathrm{FW} / \mathrm{m}^{2}$ for the completely ripened heavy clay soils, the nearly ripened heavy clay soils and the sandy loam soils. Since no difference was found between both 'heavy clay' soil classes, the dataset with all DSDS was split up in two subsets based on grain size distribution: sites with more than 30\% sand were grouped as 'sandy loam' sites (DMD1, APV8, KDG4, SDD3, OSM4, RVD1), the other DSDS were the sites with 'heavy clay' soils. Data for the time since disposal (TSD) were categorised in 4 classes: DSDS constructed (1) before 1950, (2) between 1950 and 1970, (3) between 1970-1982 and (4) since 1982. Average biomass for these classes was (1) 68.5 , (2) 24.2 , (3) 14.5 , (4) $23.3 \mathrm{~g} \mathrm{FW} / \mathrm{m}^{2}$. However, during the construction of the model, results indicated that a clustering of data in two periods (1 vs. 2-3-4) was appropriate. 
The selected linear model for earthworm biomass on DSDS is presented in Table 5. The biomass is mainly determined by TSD and grain size class (GSC), with earthworm biomass being lowest for recent heavy clay DSDS and highest for sandy loam DSDS with a TSD higher than 40 years. The negative influence of $\mathrm{Cu}$ pollution on earthworm biomass is very low relative to both TSD and grain size and might be compensated by the positive influence of high $\mathrm{P}$ concentrations as indicated by the linear model. Correlation between $\mathrm{Cu}$ and $\mathrm{P}$ is positive and significant $\left(\mathrm{R}^{2}=0.47, \mathrm{p}=0.001\right)$. In Fig. 6 the low relevance of adding the $\mathrm{Cu}$ pollution status to the basic model is clearly demonstrated. Neither soil chemical, nor soil physical variables had an additive significant influence on the model.

4. Discussion

\subsection{Comparison between DSDS and surrounding alluvial soils}

Compared to available data for Flanders (Muys and Lust, 1992; Neirynck et al., 2000), and for alluvial soils in the Netherlands (Faber et al., 2000), normal to high earthworm biomass was found in the polluted OSZ and the sandy loam DSDS, and rather low biomass was observed in the heavy clay DSDS. Muys and Lust (1992) reported values in forest soils between less than 1 and $133 \mathrm{~g} \mathrm{FW} / \mathrm{m}^{2}$. Neirynck et al. (2000) found on a loamy acid brown forest soil a minimum biomass of $<1 \mathrm{~g} \mathrm{FW} / \mathrm{m}^{2}$ and a maximum of $37 \mathrm{~g} \mathrm{FW} / \mathrm{m}^{2}$. The biomass was strongly related to dominant tree species. Both authors used the combined formalin extraction and soil core excavation method. Faber et al. (2000) reported values for floodplains excavated for clay reclamation along the Waal and Rhine river (Netherlands) based on hand sorting of excavated soil cores. Biomass ranged between 52.7-84.5 g FW/ $\mathrm{m}^{2}$ for the higher parts, 2.9-26.1 $\mathrm{g} \mathrm{FW} / \mathrm{m}^{2}$ for the lower parts and 22.2-49.1 $\mathrm{g} \mathrm{FW} / \mathrm{m}^{2}$ for the reference sites. Didden (2001) observed an average biomass of $80.4 \mathrm{~g} \mathrm{FW} / \mathrm{m}^{2}$ and a density of $384 \mathrm{~N} / \mathrm{m}^{2}$ on grassland soils (20 sites) in the Netherlands, based on hand sorting of excavated soil cores.

Data of Yeates and Orchard (1994) suggested that earthworms in superficially contaminated areas were also feeding on less polluted soil material from deeper in the profile, and in the highest polluted sites closest to smelters, only the endogeic species Aporrectodea caliginosa Savigny survived (Bengtsson and Tranvik, 1989). This behaviour may also explain the relatively high earthworm biomass found at polluted OSZ. In strongly degraded and acidified forest soils in Flanders, only epigeic earthworms could survive (Muys and Lust, 1992). Spurgeon et al. (1996) determined earthworm biomass and abundance in a gradient in the vicinity of a smelter. No earthworms were found on the sites closest to the smelter with accumulation of undecomposed leaf litter, only Lumbricus species were found in the intermediate sites and both Lumbricus species and endogeic species were found farthest away. Morgan and Morgan (1999) focused on the importance of the vertical distribution of metals within the soil profile for heavy metal exposure and uptake by earthworms occupying different ecological niches with specific food preferences. Hence, the high relative proportion of endogeic earthworms on the polluted OSZ might be a consequence of the concentration of pollutants in the upper soil horizons. For the slightly polluted floodplains $(\mathrm{Cd}<6.8 \mathrm{mg} / \mathrm{kg}$ dry soil, $\mathrm{Zn}<739 \mathrm{mg} / \mathrm{kg}$ dry soil, $\mathrm{Cu}<133 \mathrm{mg} / \mathrm{kg}$ dry soil) of the Waal river (Netherlands) the pollution was found to be of less importance for species composition and diversity of the functional groups of the invertebrate fauna (Ma et al., 1997).

\subsection{Influence of time since disposal and DSDS properties on earthworm populations}


Soil characteristics on DSDS are, apart from the pollution status, optimal to very prosperous for earthworms: high SOM content, mull-type humus forms, high carbonate contents and subsequent optimal $\mathrm{pH}$. Earthworm biomass can not be directly linked to heavy metal pollution, as the sediment substrate is also enriched by PCBs, PAHs and other pollutants. However, in accordance with the Flemish Decree on Soil Sanitation (VLAREBO, 1996), heavy metal contamination in DSDS with especially $\mathrm{Cd}, \mathrm{Cr}$ and $\mathrm{Zn}$ was considered more severe than for other pollutants (Vandecasteele et al., 2000). Earthworms are very sensitive to $\mathrm{Cu}$ pollution (Ma, 1982; Ma et al., 1983). Higher soil $\mathrm{Cu}$ concentrations result in a longer period before subadult stage and adulthood is reached or even in the inability to reach adulthood (Ma, 1983; Spurgeon and Hopkin, 1996). In areas with topsoils contaminated with $\mathrm{Cu}, \mathrm{Cr}$ and $\mathrm{As}$ as a result of the use of timber preservatives, lower earthworm biomass was found at higher $\mathrm{Cu}$ concentrations. No higher tissue concentrations were encountered excluding food chain effects for $\mathrm{Cu}$ (Yeates and Orchard, 1994). In optimal conditions with abundance of food and absence of predation, populations of juvenile L. rubellus treated with $362 \mathrm{mg} \mathrm{Cu} / \mathrm{kg}$ dry soil showed negative growth rates as the minimum body weight to reach adulthood was never reached (Ma, 1984). Klok and De Roos (1996) calculated that the critical threshold for major danger of extinction on the population level for L. rubellus was 200-300 $\mathrm{mg} \mathrm{Cu} / \mathrm{kg}$ dry soil. Stress due to sublethal toxicant concentrations for earthworms results in a decreased metal detoxification (Hönsi et al., 2003), a reduced cocoon production (Siekierska and Urbanska-Jasik, 2002) or a failure to reach adulthood (Ma, 1984). Filser et al. (1995) concludes from a literature review that higher SOM content reduces $\mathrm{Cu}$ toxicity to a great extent. Our results did not indicate a large influence of soil $\mathrm{Cu}$ concentrations on earthworm biomass, not even for the most polluted site (RVD1, > $600 \mathrm{mg} \mathrm{Cu} / \mathrm{kg}$ dry soil). Interpretation of this observation is not straightforward. The DSDS might be characterised by a low $\mathrm{Cu}$ bioavailability. Alternatively, the rate of colonisation and/or soil physicochemical properties may be the more important limiting factors than pollution status for earthworm biomass. DSDS are quickly colonised by epigeic earthworms, since even for sites that are flooded during the winter and a large part of the spring (BVP5, GTH2, SEP3) earthworms were found. In contrast to the initially fast colonisation, it takes a rather long time (at least 40 years) to reach a biomass higher than $30 \mathrm{~g} \mathrm{FW} / \mathrm{m}^{2}$.

The soil profile of DSDS deviates from normal soil profiles, as the soil organic matter content is high throughout the whole soil profile, while it is concentrated in the topsoil for normal alluvial soils. On the DSDS, the earthworm population was dominated by epigeic species, especially by L. rubellus. The pollution status of the soil did not prevent the cocoons to become juveniles and juvenile earthworms to reach adulthood. The absence of endogeic and anecic earthworms on recent DSDS might be a consequence of both the ecological stress and the colonisation strategy. Both categories are known to have a slow colonisation rate (Kstrategy). Endogeic worms are also known to feed on large amounts of soils and consequently have a more intense contact (higher exposure) with the soil pollution. Both the pollution and the lower oxygen availability in the profile can be a reason for their absence. Earthworms play an important role in SOM decomposition and subsequent incorporation in the mineral soil (Ma, 1984; Edwards and Fletcher, 1988). The slow colonisation or the adverse effects of polluted soils on soil organisms can result in a hampered SOM decomposition (Yeates and Orchard, 1994). 


\subsection{Ecological risk assessment}

In risk assessment based on trophic chains of several species inhabiting alluvial plains and floodplains, earthworms will play an important role as they can form up to $80 \%$ of the soil faunal biomass. A general trend is that sandy loam DSDS seem very prosperous for earthworms, while heavy clay DSDS are less suited. In general, it can be concluded that relative to the surrounding environment, earthworm biomass is four times lower at heavy clay DSDS. However, total biomass might be a biased indicator, as not all ecological categories of earthworms are evenly susceptible to predation. Epigeic earthworms live on the soil surface, endogeic earthworms stay in the soil, while anecic earthworms are only on the soil surface at night.

In general, $\mathrm{Cd}$ is the most important pollutant for food chain transfer, while $\mathrm{Cu}$ is the most important element for earthworm survival. This means that for soils with low $\mathrm{Cu}$ pollution but with high Cd pollution there is a larger risk as more earthworms with higher $\mathrm{Cd}$ concentrations are available for predation, while in the opposed case less earthworms can survive. The results of this study point at the colonisation rate of a polluted site as another factor in the risk assessment of DSDS. Risk assessment models focus on the heavy metal uptake and transfer by earthworms. Knowledge of earthworm heavy metal tissue concentrations is essential for risk assessment of heavy metal biomagnification. Before using an appropriate model for a selected area, differences in earthworm biomass related to different soil properties must be considered. If no large differences exist between the reference situation (in this case ALL) and the polluted site, a model without correction for biomass can be used, i.e., an equal biomass at all sites is inherently assumed. However, if differences between the reference and the polluted site are large, the food availability is subject to spatial variability. Spatial patterns in food availability must be included in risk assessment, as is the case for spatial patterns of soil pollution (Kooistra et al., 2001) and for differences in feeding behaviour of target animals (Heikens et al., 2001). Both earthworm tissue concentrations and data on earthworm biomass might thus be necessary for a good ecological risk assessment of biomagnification.

Secondary poisoning can result in changes at higher organisation levels of the biological system. An indirect effect of soil pollution is a possible food shortage for higher levels in the food chain (Hörnfeldt and Nyholm, 1996; Klok et al., 2000) or a changed, less optimal diet (Van den Brink et al., 2003). Secondary poisoning is highly dependent on the configuration of the polluted area and ecology of the target species (Menzie et al., 1992). Sandy soils, waterlogged soils, swamps and lakes, forests and urbanisation were found to have a negative impact on Little Owl presence. As the preferred soil types are also optimal for earthworms, food availability was thought to be a major factor for the Little Owl habitat (Van Nieuwenhuyse et al., 2001).

\section{Conclusions}

We focused on earthworm biomass determination as additional information for risk assessment of heavy metal biomagnification through the foodweb on DSDS relative to the surrounding alluvial plains. In general it can be concluded that relative to the surrounding environment, earthworm biomass is four times lower for contaminated dredged sedimentderived heavy clay soils and comparable to alluvial soils for sandy loam DSDS. Risks for secondary poisoning at the more polluted heavy clay DSDS are thus partially compensated by the lower earthworm biomass. However, not all ecological categories of earthworms are 
equally susceptible to predation. Endogeic earthworms stay in the soil, while anecic earthworms are only at night at the soil surface.

It was found that recent sediment landfills were colonised by epigeic earthworms rather fast, but larger earthworm populations were only observed in sites of more than 50 years old. Relative to polluted overbank sedimentation zones, impact of dredged sediment disposal on earthworm communities is large as data suggest that it takes more than 40 years until all ecological categories have colonised the sites. A clear difference was observed between heavy clay and sandy loam DSDS with a distinct higher earthworm biomass on the sandy loam DSDS.

For L. rubellus, a negative relation was found between the highest recorded body weight and the clay content of the DSDS. The highest recorded adult body weight per species is thus a potential site quality parameter. Mainly time since disposal and grain size distribution determined earthworm biomass on DSDS, while considerable levels of soil pollution were merely found to influence this important population characteristic in view of risk assessment. High soil $\mathrm{Cu}$ concentrations did thus not lower the risk for $\mathrm{Cd}$ biomagnification through a reduced earthworm population. For future ecotoxicological field research on earthworm populations, inclusion of a broad range of soil physical and chemical variables is worthy of consideration.

\section{Acknowledgements}

This project was carried out with financial support from the Waterways and Marine Affairs Administration (AWZ) of the Ministry of the Flemish Community. We are grateful to Koen Willems, Koen Vervaet and Mathieu Pieters for the earthworm samplings and Carine Buysse, Els Mencke, Anya De Rop, Athanaska Verhelst and An Capieau for the accurate soil analyses.

\section{References}

Abdul Rida, A.M.M., 1992. Biosurveillance de la contamination du sol: apport de l'étude des lombriciens à l'évaluation des risques liés aux elements traces. Thèse de doctorat, Université Montpellier II, spécialité écotoxicologie et environnement.

Bengtsson, G., Tranvik, L., 1989. Critical metal concentrations for forest soil invertebrates. A review of the limitations. Water, Air, and Soil Pollution 47, 381-417.

Beyer, W.N., Miller, G., Simmers J.W., 1990. Trace elements in soil and biota in confined disposal facilities for dredged material. Environmental Pollution 65, 19-32.

Beyer, W.N., Stafford, C., 1993. Survey and evaluation of contaminants in earthworms and in soils derived from dredged material at confined disposal facilities in the great lakes region. Environmental Monitoring and Assessment 24 (2), 151-165.

Bouché, M.B., 1972. Lombriciens de France. Ecologie et Systématique. INRA Ann. Zool. Ecol. Anim., nº spécial, 72 (2).

Bouché, M.B., Aliaga, R., 1986. Contre une dégradation physique et chimique des sols et pour leur optimisation économique, l'échantillonage des lombriciens: une urgente nécessité. La Défense des Végétaux 242, 30-36. 
Brzóska, M.M., Moniuszko-Jakoniuk, J., 1998. The influence of calcium content in diet on cumulation and toxicity of cadmium in the organism. Archives of Toxicology 72, 63-73.

Darmody, R.G., Marlin, J.C., 2002. Sediments and sediment-derived soils in Illinois: pedological and agronomical assessment. Environmental Monitoring and Assessment 77, 209227.

Didden, W.A.M., 2001. Earthworm communities in grasslands and horticultural soils. Biology and Fertility of Soils 33, 111-117.

Edwards, C.A., Fletcher, K.E., 1988. Interactions between earthworms and micro-organisms in organic-matter breakdown. Agriculture, Ecosystems and Environment 24, 235-247.

Edwards, S.C., Macleod, C.L., Lester, J.N., 1998. The bioavailability of copper and mercury to the common nettle (Urtica dioica) and the earthworm Eisenia fetida from contaminated dredge spoil. Water, Air, and Soil Pollution 102, 75-90.

Eijsackers, H., 1987. The impact of heavy metals on terrestrial ecosystems: biological adaptation through behavioural and physiological avoidance. In: Ravera, O. (Ed.), Ecological assessment of environmental degradation, pollution and recovery. Elsevier Science, The Netherlands, pp. 245-259.

Faber, J.H., Burgers, J., Aukema, B., Bodt, J.M., van Kats, R.J.M., Lammertsma, D.R., Noordam, A.P., 2000. Ongewervelde fauna van ontkleide uiterwaarden. Monitoringsverslag 1999. Alterra-rapport 039, ISSN 1566-7197, Alterra, Wageningen, 69 p.

Filser, J., Fromm, H., Nagel, R.F., Winter, K., 1995. Effects of previous intensive agricultural management on micro-organisms and the biodiversity of soil fauna. Plant and Soil 170, 123129.

Granval, P., Aliaga, R., 1988. Analyse critique des connaissances sur les prédateurs de lombriciens. Gibier Faune Sauvage 5, 71-94.

Haan, W. de, Otten, K.J., Heynen, J.J.M., Folkerts, H., Elsman, M., 1998. Field monitoring of ripening of dredged material at three sites in the Netherlands (preliminary results). Water Science and Technology 36 (6-7), 371-378.

Heikens, A., Peijenburg, W.J.G.M., Hendriks, A.J., 2001. Bioaccumulation of heavy metals in terrestrial invertebrates. Environmental Pollution 113, 385-393.

Heine, O., Larink, O., 1993. Food and cast analyses as a parameter of turn-over of materials by earthworms (Lumbricus terrestris L.). Pedobiologia 37, 245-256.

Hendriks, A.J., Ma, W.C., Brouns, J.J., de Ruiter-Dijkman, E.M., Gast, R., 1995. Modelling and monitoring organochlorine and heavy metal accumulation in soils, earthworms and shrews in Rhine-Delta floodplains. Environmental Contamination and Toxicology 29, 115127.

Hönsi, T.G., Stubberud, H.E., Andersen, S., Stenersen, J., 2003. Lysosomal fragility in earthworms (Eisenia veneta) exposed to heavy metal contaminated soils from two abandoned pyrite ore mines in southern Norway. Water, Air, and Soil Pollution 142, 27-37. 
Hörnfeldt, B., Nyholm, E.I., 1996. Breeding performance of Telmalm's owl in a heavy metal pollution gradient. Journal of Applied Ecology 33, 377-386.

Klok, C., de Roos, A.M., 1996. Population level consequences of toxicological influences on individual growth and reproduction in Lumbricus rubellus (Lumbricidae, Oligochaeta). Ecotoxicology and Environmental Safety 33, 118-127.

Klok, C., de Roos, A.M., Broekhuizen, S., van Apeldoorn, R.C., 2000. Effects of heavy metals on the badger Meles meles: interaction between habitat quality and fragmentation. In: Kamminga, J.E., Laskowski, R. (Eds), Demography in Ecotoxicology. Wiley, Sussex.

Kooistra, L., Leuven, R.S.E.W., Nienhuis, P.H., Wehrens, R., Buydens, L.M.C., 2001. A procedure for incorporating spatial variability in ecological risk assessment of Dutch river floodplains. Environmental Management 28 (3), 359-373.

Kreis, B., Edwards, P., Cuendet, G., Tarradellas, J., 1987. The dynamics of PCBs between earthworm populations and agricultural soils. Pedobiologia 30, 379-388.

Ma, W.C., 1982. The influence of soil properties and worm-related factors on the concentration of heavy metals in earthworms. Pedologia 24, 109-119.

Ma, W.C., 1984. Sublethal toxic effects of copper on growth, reproduction and litter breakdown activity in the earthworm Lumbricus rubellus, with observations on the influence of temperature and soil pH. Environmental Pollution (Series A) 33, 207-219.

Ma, W.C., 1988. Toxicity of copper to lumbricid earthworms in sandy agricultural soils amended with $\mathrm{Cu}$-enriched organic waste materials. Ecological Bulletins 39, 53-56.

Ma, W.C., Edelman, T., van Beersum, I., Jans, T., 1983. Uptake of cadmium, zinc, lead, and copper by earthworms near a zinc-smelting complex: influence of soil $\mathrm{pH}$ and organic matter. Bulletin of Environmental Contamination and Toxicology 30, 424-427.

Ma, W.C., Siepel, H., Faber, J.H., 1997. Onderzoek naar mogelijke ecotoxicologische effecten van bodemverontreiniging in de uiterwaarden op de terrestrische invertebratenfauna. IBN-rapport 289. IBN-dlo, wageningen. 79 p.

Martin, M.H., Bullock, R.J., 1994. The impact and fate of heavy metals in an oak woodland ecosystem. In: Ross, S.M. (Ed.), Toxic Metals in Soil-Plant Systems. John Wiley, Chichester, pp. 327-366.

Massman, J.W., Butchart, C.D., 2002. Infiltration characteristics, performance, and design of storm water facilities. WA-RD 483.1, Washington State Transportation Centre, University of Washington, $34 \mathrm{p}$.

Menzie, C.A., Burmaster, D.E., Freshman, J.S., Callahan, C.A., 1992. Assessment of methods for estimating ecological risk in the terrestrial component: a case study at the Baird and McGuire superfund site in Holbrook, Massachusetts. Environmental Toxicology and Chemistry 11, 245-260. 
Morgan, J.E., Morgan, A.J., 1999. The accumulation of metals ( $\mathrm{Cd}, \mathrm{Cu}, \mathrm{Pb}, \mathrm{Zn}$ and $\mathrm{Ca}$ ) by two ecologically contrasting earthworm species (Lumbricus rubellus and Aporrectodea caliginosa): implications for ecological testing. Applied Soil Ecology 13, 9-20.

Muys, B., 1993. Synecologische evaluatie van regenwormactiviteit en strooiselafbraak in de bossen van het Vlaamse gewest als bijdrage tot een duurzaam bosbeheer. Proefschrift voorgedragen tot het behalen van de graad van Doctor in de Landbouwkundige Wetenschappen. Universiteit Gent, Faculteit Landbouwkundige en Toegepaste Biologische Wetenschappen.

Muys, B., Lust, N., 1992. Inventory of the earthworm communities and the state of litter decomposition in the forest of Flanders, Belgium, and its implications for forest management. Soil Biology and Biochemistry 24 (12), 1677-1681.

Neirynck, J., Mirtcheva, S., Sioen, G., Lust, N., 2000. Impact of Tilia platyphyllos Scop., Fraxinus excelsior L., Acer pseudoplatanus L., Quercus robur L. and Fagus sylvatica L. on earthworm biomass and physico-chemical properties of a loamy topsoil. Forest Ecology and Management 133, 275-286.

Siekierska, E., Urbanska-Jasik, D., 2002. Cadmium effect on the ovarian structure in earthworm Dendrobaena veneta (Rosa). Environmental Pollution 120, 289-297.

Spurgeon, D.J., Hopkin, S.P., 1996. Effects of metal-contaminated soils on the growth, sexual development, and early cocoon production of the earthworm Eisenia fetida, with particular reference to zinc. Ecotoxicology and Environmental Safety 35, 86-95.

Spurgeon, D.J., Sandifer, R.D., Hopkin, S.P., 1996. The use of macro-invertebrates for population and community monitoring of metal contamination - indicator taxa, effect parameters and the need for a soil invertebrate prediction and classification scheme (SIVPACS). In: van Straalen, N.M., Krivolutsky, D.A. (Eds), Bioindicator systems for soil pollution. Kluwer Academic Publishers, Dordrecht/Boston/London, pp. 95-110.

Suter, G.W. II, Efroymson, R.A., Sample, B.E., Jones, D.S., 2000. Ecological risk assessment for contaminated sites. Lewis publishers, Boca Raton, 438 pp.

Vandecasteele, B., De Vos, B., Lauriks, R., Buysse, C., Mergaert, K., 2000. Baggergronden in Vlaanderen. Resultaten van de terreininventarisatie naar geografische omvang en verontreiniging. Mededelingen van het Instituut voor Bosbouw en Wildbeheer 2000-1. IBW, Geraardsbergen.

Vandecasteele, B., De Vos, B., Tack, F.M.G., 2003. Temporal-spatial trends in heavy metal contents in sediment-derived soils along the Sea Scheldt river (Belgium). Environmental Pollution 122, 7-18.

Van den Brink, N.W., Groen, N.M., De Jonge, J., Bosveld, A.T.C., 2003. Ecotoxicological suitability of floodplain habitats in The Netherlands for the little owl (Athene noctua vidalli). Environmental Pollution 122, 127-134.

van Driel, W., Nijssen, J.P.J., 1988. Development of dredged material disposal sites: implications for soil, flora and food quality. In: Salomons, W., Förstner, U. (Eds.), Chemistry 
and biology of solid waste. Dredged material and mine tailings. Berlin, Springer-Verlag, pp. 101-126.

Van Nieuwenhuyse, D., Leysen, M., Steenhoudt, K., 2001. Analysis and spatial prediction of Little Owl Athene noctua distribution in relation to its living environment in Flanders (northern Belgium). Modelling spatial distribution through logistic regression. Oriolus 67 (23), 32-51.

VLAREBO, 1996. Besluit van de Vlaamse regering houdende vaststelling van het Vlaams reglement betreffende de bodemsanering. Belgisch Staatsblad, 27 maart 1996.

Yeates, G.W., Orchard, V.A., 1994. Impact of pasture contamination by copper, chromium, arsenic timber preservative on soil biological activity. Biology and Fertility of Soils 18, 200208. 
Table 1. Properties of the sampled unaffected alluvial soils (ALL), the dredged sediment-derived soils (DSDS) and overbank sedimentation zones (OSZ). Earthworm density and biomass (based on a combination of formalin extraction and soil core excavation) are given in the last columns. Values in parentheses are standard deviations for six replicates

\begin{tabular}{|c|c|c|c|c|c|c|c|c|c|c|c|}
\hline \multirow[t]{2}{*}{ Site } & \multirow[t]{2}{*}{ River } & Soil & \multirow[t]{2}{*}{ Land use } & \multirow{2}{*}{$\begin{array}{c}\text { clay } \\
\%\end{array}$} & \multirow{2}{*}{$\begin{array}{c}\text { TOC } \\
\%\end{array}$} & \multirow{2}{*}{$\begin{array}{c}\text { EC } \\
\mu S / c m\end{array}$} & \multirow[t]{2}{*}{$\mathrm{pH}-\mathrm{H}_{2} \mathrm{O}$} & \multirow{2}{*}{$\begin{array}{c}\mathrm{CaCO}_{3} \\
\%\end{array}$} & \multirow{2}{*}{$\begin{array}{c}\text { DW soil } \\
\%\end{array}$} & \multirow{2}{*}{$\begin{array}{l}\text { Density } \\
\mathrm{N} / \mathrm{m}^{2}\end{array}$} & \multirow{2}{*}{$\begin{array}{c}\text { Biomass } \\
\mathrm{g} / \mathrm{m}^{2}\end{array}$} \\
\hline & & type & & & & & & & & & \\
\hline BEL1 & & ALL & oak plantation & $33(4)$ & $8.5(1.2)$ & $224(88)$ & $5.7(0.2)$ & $1.9(0.3)$ & $67.2(3.6)$ & $164(67)$ & $88.9(26.7)$ \\
\hline BVP1 & & ALL & pasture & $26(1)$ & $6.1(0.6)$ & $197(21)$ & $6.9(0.2)$ & $2.2(0.8)$ & $63.6(2)$ & $485(253)$ & $157.5(141)$ \\
\hline \multirow[t]{2}{*}{ SEPM } & Upper Scheldt & DSDS & alder plantation & $32(1)$ & $13.8(0.6)$ & $177(20)$ & $7.5(0.1)$ & $5.3(0.9)$ & $64.5(2.4)$ & $139(41)$ & $13.4(5.5)$ \\
\hline & & osZ & pasture & $35(1)$ & $13(1.2)$ & $198(14)$ & $6.7(0.5)$ & $2.5(0.4)$ & $57.8(5.5)$ & $119(38)$ & $31.1(10)$ \\
\hline DMD1 & & osz & pasture & $25(2)$ & $10.9(0.5)$ & $249(54)$ & $6.5(0.2)$ & $2.3(0.4)$ & $53(3.7)$ & $374(185)$ & $78.9(44.8)$ \\
\hline \multirow[t]{2}{*}{ GTH9 } & Leie & DSDS & elder brushwood & $42(3)$ & $8.7(1.9)$ & $257(37)$ & $7.4(0.1)$ & $11.1(1)$ & $63.5(2.7)$ & $45(45)$ & $9.9(11.8)$ \\
\hline & & osz & pasture & $19(5)$ & $1.8(1)$ & $312(181)$ & $7.9(0.3)$ & $4.4(1.9)$ & NA & $215(95)$ & $47.2(18.7)$ \\
\hline \multirow[t]{2}{*}{ SEP3 } & Upper Scheldt & osz & pasture & $36(3)$ & $10.7(1.4)$ & $227(40)$ & $7.3(0.2)$ & $4.6(1.1)$ & $66.4(3.6)$ & $30(44)$ & $10.8(15.2)$ \\
\hline & & ALL & pasture & $31(4)$ & $5.1(2.2)$ & $219(54)$ & $7.2(0.2)$ & $2.4(0.4)$ & $72.1(5.9)$ & $48(31)$ & $24.9(9.4)$ \\
\hline
\end{tabular}


Table 2. Elemental contents in the sampled unaffected alluvial soils (ALL), the dredged sediment-derived soils (DSDS) and overbank sedimentation zones (OSZ). Cd, $\mathrm{Cu} \mathrm{Cr}, \mathrm{Pb}, \mathrm{Zn}$, $\mathrm{P}$ and $\mathrm{S}$ are aqua regia-extracted and are expressed as $\mathrm{mg} / \mathrm{kg}$ dry soil. Values in parentheses are standard deviations for six replicates

\begin{tabular}{|c|c|c|c|c|c|c|c|c|}
\hline Site & Soil & Cd & $\mathrm{Cr}$ & $\mathrm{Cu}$ & $\mathbf{P b}$ & $\mathrm{Zn}$ & $\mathbf{P}$ & $\mathbf{S}$ \\
\hline & type & $\mathrm{mg} / \mathrm{kg}$ & $\mathrm{mg} / \mathrm{kg}$ & $\mathrm{mg} / \mathrm{kg}$ & $\mathrm{mg} / \mathrm{kg}$ & $\mathrm{mg} / \mathrm{kg}$ & $\mathrm{mg} / \mathrm{kg}$ & $\mathrm{mg} / \mathrm{kg}$ \\
\hline \multirow[t]{2}{*}{ BEL1 } & DSDS & $9.2(2.7)$ & $216(31)$ & $209(30)$ & $216(36)$ & 1558 (269) & $5279(988)$ & $1905(300)$ \\
\hline & ALL & $1.6(0.3)$ & $88(13)$ & $47(8)$ & $122(22)$ & $276(39)$ & 1364 (215) & $1337(218)$ \\
\hline \multirow[t]{2}{*}{ BVP1 } & DSDS & $6.8(0.9)$ & $320(16)$ & $156(53)$ & $126(21)$ & $810(178)$ & $2870(318)$ & $1780(382)$ \\
\hline & ALL & $0.9(0.1)$ & $66(3)$ & $21(2)$ & $43(5)$ & $132(11)$ & $976(40)$ & $1092(106)$ \\
\hline \multirow[t]{2}{*}{ SEPM } & DSDS & $11.4(2)$ & $269(33)$ & $136(12)$ & $408(35)$ & 2053 (197) & 2105 (165) & $1692(177)$ \\
\hline & Osz & $6.2(0.5)$ & $156(11)$ & $89(12)$ & $278(29)$ & 1112 (198) & $1182(126)$ & $1530(142)$ \\
\hline \multirow[t]{2}{*}{ DMD1 } & DSDS & $5.7(2.6)$ & $429(232)$ & $89(39)$ & $197(59)$ & $889(413)$ & $2034(614)$ & $1611(405)$ \\
\hline & osz & $1.4(0.2)$ & $83(7)$ & $120(14)$ & $518(74)$ & $352(18)$ & 1438 (167) & $1409(80)$ \\
\hline \multirow[t]{2}{*}{ GTH9 } & DSDS & $23(2.2)$ & $515(43)$ & $332(29)$ & $474(36)$ & $2742(163)$ & $5087(334)$ & $2116(376)$ \\
\hline & osz & $4(3.4)$ & $118(82)$ & $65(53)$ & $104(83)$ & $524(433)$ & 1306 (817) & 629 (389) \\
\hline \multirow[t]{2}{*}{ SEP3 } & osz & $34.3(12.2)$ & $816(309)$ & $106(21)$ & $341(103)$ & 2042 (495) & 3485 (969) & $1603(88)$ \\
\hline & ALL & $0.7(0.1)$ & $69(10)$ & $20(6)$ & $80(59)$ & $149(15)$ & 1974 (789) & $844(228)$ \\
\hline
\end{tabular}


Table 3. Soil physical properties, earthworm density and biomass for the dredged sediment-derived soils (DSDS) where earthworms were sampled. Earthworm density and biomass are based on formalin extraction only. Highest body weight for an adult $L$. rubellus is recorded in the column 'L. rubellus'. Values in parentheses are standard deviations for six replicates $(\mathrm{TSD}=$ time since disposal, P.R. $=$ penetration resistance,

\begin{tabular}{|c|c|c|c|c|c|c|c|c|c|c|c|c|c|}
\hline Site & River/Canal & Land use & Sampling & $\begin{array}{c}\text { Clay } \\
\%\end{array}$ & $\begin{array}{c}\text { DW soil } \\
\%\end{array}$ & $\begin{array}{c}\text { Density } \\
\mathrm{N} / \mathrm{m}^{2}\end{array}$ & $\begin{array}{c}\text { Biomass } \\
\mathrm{g} / \mathrm{m}^{2}\end{array}$ & $\begin{array}{c}\text { L. rubellus } \\
\mathrm{g}\end{array}$ & $\begin{array}{c}\text { TSD } \\
\text { (year) }\end{array}$ & $\begin{array}{l}\text { P.R. } \\
\mathrm{MPa}\end{array}$ & $\begin{array}{c}\text { Bulk density } \\
\qquad \mathrm{kg} / \mathrm{m}^{3}\end{array}$ & $\begin{array}{c}\text { Permeability } \\
\text { cm/day }\end{array}$ & $\begin{array}{c}\text { Ripening } \\
\text { factor }\end{array}$ \\
\hline APV8 & Sea Scheldt & poplar plantation & Fall 2001 & $14(2)$ & $81.9(6.5)$ & $244(26)$ & $128.0(56.6)$ & 1.800 & 70 & 2.44 & 1016 & 10 & 0.21 \\
\hline DMD1 & Leie & pasture & Fall 2001 & $15(4)$ & NA & $28(13)$ & $7.6(3.1)$ & 1.633 & 30 & 2.91 & 1287 & 5 & 0.35 \\
\hline SDD3 & Canal Ghent-Bruges & poplar plantation & Spring 2002 & $20(3)$ & $80.6(2.9)$ & $97(25)$ & $118.5(56.7)$ & 2.587 & 60 & 2.16 & 1167 & 213 & 0.30 \\
\hline KDG4 & Sea Scheldt & pasture & Fall 2002 & $21(7)$ & $79.3(6.9)$ & $55(29)$ & $32.7(31.3)$ & 2.268 & 14 & 3.09 & 1296 & 1529 & 0.24 \\
\hline OSM4 & Upper Scheldt & pasture & Fall 2002 & $25(4)$ & $76(1.6)$ & $48(9)$ & $48.1(8.1)$ & 0.487 & 40 & 2.42 & 1140 & 24 & 0.23 \\
\hline APV1 & Sea Scheldt & poplar plantation & Fall 2001 & $26(2)$ & $61.1(10.8)$ & $154(60)$ & $59(30)$ & 1.110 & 70 & 0.83 & 1193 & 36 & 1.04 \\
\hline BVP1 & Upper Scheldt & willow brushwood & Fall 2001 & $28(5)$ & $63(1.9)$ & $156(40)$ & $20(8.3)$ & 1.006 & 6 & 0.75 & 1099 & 4 & 0.96 \\
\hline SEPM & Upper Scheldt & alder plantation & Fall 2001 & $32(1)$ & $64.5(2.4)$ & $117(46)$ & $11.4(6.1)$ & 0.421 & 40 & 1.06 & 1013 & 4 & 0.43 \\
\hline RVD1 & Canal Ghent-Bruges & willow brushwood & Fall 2002 & $41(2)$ & $54.5(2.5)$ & $53(25)$ & $11.3(4.5)$ & 0.569 & 25 & 2.07 & 867 & 4 & 0.72 \\
\hline AKM2 & Leie & ash plantation & Fall 2002 & $35(3)$ & $69.8(4.7)$ & $148(51)$ & $19.2(10.7)$ & 0.716 & 16 & 1.56 & 1058 & 4 & 0.50 \\
\hline LMM3 & Upper Scheldt & ash plantation & Fall 2001 & $37(1)$ & $53.8(3.1)$ & $381(216)$ & $33.5(9.3)$ & 0.728 & 40 & 1.6 & 899 & 56 & 0.84 \\
\hline GTH2 & Leie & willow brushwood & Fall 2002 & $37(1)$ & $60.3(6.8)$ & $110(46)$ & $8.5(2.8)$ & 0.461 & 22 & 1.12 & 989 & 30 & 0.70 \\
\hline LMM2 & Upper Scheldt & ash plantation & Fall 2001 & $38(3)$ & $54.8(3.9)$ & $145(39)$ & $9.8(4.4)$ & 1.062 & 40 & 2.46 & 896 & 181 & 0.71 \\
\hline BEL1 & Leie & willow brushwood & Fall 2001 & $39(5)$ & NA & $125(52)$ & $15.7(7.1)$ & 0.586 & 16 & 3.5 & 800 & 356 & 0.67 \\
\hline KAMW & Sea Scheldt & pasture & Fall 2002 & $40(3)$ & $57.7(3.2)$ & $89(34)$ & $33.1(8.1)$ & 0.614 & 70 & 1.12 & 850 & 83 & 0.68 \\
\hline BVP5 & Upper Scheldt & willow brushwood & Fall 2002 & $41(2)$ & $66.1(5.6)$ & $113(42)$ & $10.8(5.3)$ & 0.278 & 6 & 1.04 & 995 & 29 & 0.55 \\
\hline GTH9 & Leie & elder brushwood & Fall 2001 & $42(3)$ & $63.5(2.7)$ & $32(22)$ & $7.3(6.8)$ & 0.963 & 25 & 1.14 & 882 & 490 & 0.55 \\
\hline RAE2 & Leie & willow brushwood & Spring 2002 & $43(2)$ & $62.7(2.9)$ & $3(5)$ & $0.4(0.7)$ & NA & 6 & 0.87 & 743 & 595 & 0.67 \\
\hline ZWI3 & Upper Scheldt & abandoned arable land & Fall 2002 & $45(2)$ & $69(0.9)$ & $175(31)$ & $27.2(6.8)$ & 0.497 & 20 & 2.06 & 962 & 79 & 0.43 \\
\hline
\end{tabular}

$\mathrm{NA}=$ not assessed) 
Table 4. Properties of the dredged sediment-derived soils (DSDS) selected for earthworm sampling. $\mathrm{Cd}, \mathrm{Cu}, \mathrm{Cr}, \mathrm{Pb}, \mathrm{Zn}, \mathrm{P}$ and $\mathrm{S}$ are aqua regia-extracted and are expressed as $\mathrm{mg} / \mathrm{kg}$ dry soil, $\mathrm{TOC}, \mathrm{CaCO}_{3}$ and $\mathrm{EC}$ are expressed in \%. Values in parentheses are standard deviations for six replicates

\begin{tabular}{|c|c|c|c|c|c|c|c|c|c|c|c|}
\hline Site & $\mathrm{CaCO}_{3}$ & TOC & EC & $\mathrm{pH}-\mathrm{H}_{2} \mathrm{O}$ & Cd & $\mathrm{Cr}$ & $\mathrm{Cu}$ & $\mathrm{Pb}$ & $\mathrm{Zn}$ & $\mathbf{P}$ & $\mathbf{S}$ \\
\hline & $\%$ & $\%$ & $\mu \mathrm{S} / \mathrm{cm}$ & & $\mathrm{mg} / \mathrm{kg}$ & $\mathrm{mg} / \mathrm{kg}$ & $\mathrm{mg} / \mathrm{kg}$ & $\mathrm{mg} / \mathrm{kg}$ & $\mathrm{mg} / \mathrm{kg}$ & $\mathrm{mg} / \mathrm{kg}$ & $\mathrm{mg} / \mathrm{kg}$ \\
\hline APV8 & $2.7(1.1)$ & $2.8(0.4)$ & $154(17)$ & $7.5(0.2)$ & $1.6(0.5)$ & $66(18)$ & $31(9)$ & $62(10)$ & $350(67)$ & 841 (146) & $624(187)$ \\
\hline DMD1 & $4.3(0.8)$ & $10(3.5)$ & $132(28)$ & $7.4(0.1)$ & $5.7(2.6)$ & $429(232)$ & $89(39)$ & $197(59)$ & $889(413)$ & $2034(614)$ & $1611(405)$ \\
\hline SDD3 & $6(1.5)$ & $1.3(0.6)$ & 1447 (1519 & $7.6(0.2)$ & $3.3(1.2)$ & $109(36)$ & $53(22)$ & $98(45)$ & $513(285)$ & $1242(287)$ & $1545(2447)$ \\
\hline KDG4 & $4.4(2)$ & $3.4(1.6)$ & $170(73)$ & $7.5(0.2)$ & $6.3(5.5)$ & $600(474)$ & $319(221)$ & 235 (115) & $1321(936)$ & $4124(2449)$ & $1373(904)$ \\
\hline OSM4 & $5(1.1)$ & $10.7(1.3)$ & $193(69)$ & $7.6(0.2)$ & $4.9(0.9)$ & $378(60)$ & $226(48)$ & $457(71)$ & $1805(348)$ & 2592 (518) & 1735 (148) \\
\hline APV1 & $6.3(0.7)$ & $5.2(0.8)$ & 235 (19) & $7.5(0.1)$ & $3.2(0.2)$ & $157(28)$ & $96(7)$ & $161(5)$ & $661(30)$ & $1536(77)$ & 849 (91) \\
\hline BVP1 & $10.3(1.3)$ & $3.9(1.3)$ & $246(95)$ & $7.5(0)$ & $6.8(0.9)$ & $320(16)$ & $156(53)$ & $126(21)$ & $810(178)$ & 2870 (318) & $1780(382)$ \\
\hline SEPM & $5.3(0.9)$ & $13.8(0.6)$ & $177(20)$ & $7.5(0.1)$ & $11.4(2)$ & 269 (33) & $136(12)$ & $408(35)$ & 2053 (197) & 2105 (165) & 1692 (177) \\
\hline RVD1 & $2.7(0.9)$ & $11.4(1.1)$ & $1490(894)$ & $6.7(0.3)$ & $27.7(0.7)$ & 1100 (125) & $661(29)$ & 1077 (143) & $5686(170)$ & $7146(286)$ & $10300(6492)$ \\
\hline AKM2 & $8.3(0.4)$ & $5.4(1.3)$ & $198(30)$ & $7.2(0.1)$ & $13.6(1)$ & $242(15)$ & $138(6)$ & $224(18)$ & $1310(105)$ & $4328(1429)$ & 1253 (122) \\
\hline LMM3 & $13(1.8)$ & $10.2(1.3)$ & $269(36)$ & $7.4(0.1)$ & $28.7(1.7)$ & 1933 (108) & $229(10)$ & $405(10)$ & $2953(114)$ & 5724 (343) & $2334(91)$ \\
\hline GTH2 & $9.4(0.7)$ & $8.2(1.1)$ & $359(78)$ & $7.2(0.1)$ & $12.4(0.9)$ & $227(13)$ & $133(18)$ & $283(128)$ & 1339 (108) & 3849 (1077) & 1452 (259) \\
\hline LMM2 & $5.3(0.6)$ & $12.6(1.1)$ & $277(23)$ & $7.1(0.1)$ & $18.2(3.2)$ & $1121(240)$ & $159(19)$ & 347 (29) & $2243(275)$ & 3891 (420) & 2017 (129) \\
\hline BEL1 & $10.6(4)$ & $8.1(1.5)$ & $286(56)$ & $7.6(0.2)$ & $9.2(2.7)$ & $216(31)$ & $209(30)$ & $216(36)$ & 1558 (269) & 5279 (988) & $1905(300)$ \\
\hline KAMW & $4.9(0.7)$ & $10.3(0.9)$ & $361(57)$ & $7.4(0.1)$ & $4.3(0.5)$ & $422(15)$ & $210(49)$ & 336 (133) & 1205 (69) & 3145 (842) & 1622 (199) \\
\hline BVP5 & $11.5(0.7)$ & $6.6(1.3)$ & $286(51)$ & $7.5(0)$ & $13(1.2)$ & $498(79)$ & $129(19)$ & $138(22)$ & 1089 (184) & 4310 (280) & 1877 (188) \\
\hline GTH9 & $11.1(1)$ & $8.7(1.9)$ & 257 (37) & $7.4(0.1)$ & $23(2.2)$ & 515 (43) & 332 (29) & $474(36)$ & 2742 (163) & 5087 (334) & 2116 (376) \\
\hline RAE2 & $9.2(0.5)$ & $6.3(0.8)$ & 1793 (437) & $7(0)$ & $8.5(0.7)$ & 308 (48) & 182 (15) & 219 (19) & 1641 (126) & 4215 (343) & 5052 (1434) \\
\hline ZWI3 & $10.1(0.2)$ & $7.3(0.6)$ & $238(29)$ & $7.3(0)$ & $23.5(0.7)$ & 1487 (96) & $119(4)$ & $576(172)$ & 2747 (95) & $6123(1300)$ & $2023(51)$ \\
\hline
\end{tabular}


Table 5. Coefficients and descriptives for the linear model describing the sqrt(earthworm biomass $\left.\left(\mathrm{g} / \mathrm{m}^{2} \mathrm{FW}\right)\right)$ as a function of DSDS properties. Value for TSD is 0 when time since disposal $<50$ year and 1 when $>50$ year. GSC (Grain size class) is 0 when sand content $<$ $30 \%$ and 1 when sand content $>30 \%$. Cu and $\mathrm{P}$ are expressed as $\mathrm{mg} / \mathrm{kg}$ dry soil

\begin{tabular}{rrrrr} 
& Value Std. Error & $t$-value & $\operatorname{Pr}(>|t|)$ \\
\hline (Intercept) & 2.7072 & 0.6047 & 4.4767 & 0.0000 \\
GSC & 1.8407 & 0.4933 & 3.7318 & 0.0003 \\
TSD & 3.5382 & 0.5769 & 6.1334 & 0.0000 \\
GSC:TSD & 2.4179 & 0.8831 & 2.7380 & 0.0074 \\
Cu & -0.0040 & 0.0020 & -2.0085 & 0.0475 \\
P & 0.0004 & 0.0001 & 3.2326 & 0.0017
\end{tabular}


Figure 1. Typical soil profile for an overbank sedimentation zone (OSZ), a dredged sedimentderived soil (DSDS), and an unaffected alluvial soil (ALL).

Figure 2. The study area with the sampled locations.

Figure 3. (a) Earthworm density $\left(\mathrm{N} / \mathrm{m}^{2}\right)$ and (b) biomass $\left(\mathrm{g} / \mathrm{m}^{2} \mathrm{FW}\right)$ for the pairwise sampled sites (unaffected alluvial soils $=$ ALL, dredged sediment-derived soils $=$ DSDS and overbank sedimentation zones $=$ OSZ).

Figure 4. (a) Relative distribution of the earthworm biomass over the ecological categories for the pairwise sampled sites and (b) highest weight recorded for adult $L$. rubellus (unaffected alluvial soils $=$ ALL, dredged sediment-derived soils $=$ DSDS and overbank sedimentation zones $=$ OSZ). Descriptive data for the sites are given in Table 1 and 2.

Figure 5. Relative distribution of the earthworm biomass over the ecological categories for (a) sandy loam DSDS and (b) heavy clay DSDS. Descriptive data for the sites are given in Table 3 and 4 . Time since disposal (TSD) is given in the boxes.

Figure 6. Relation between residuals of the basic model: SQRT(earthworm biomass) $=$ TSD + GSC + TSD:GSC as dependent, and $\mathrm{Cu}, \mathrm{P}$ and $\mathrm{Zn}(\mathrm{mg} / \mathrm{kg}$ dry soil) as independent variables, with $\mathrm{TSD}=$ time since disposal and $\mathrm{GSC}=$ Grain size class. 


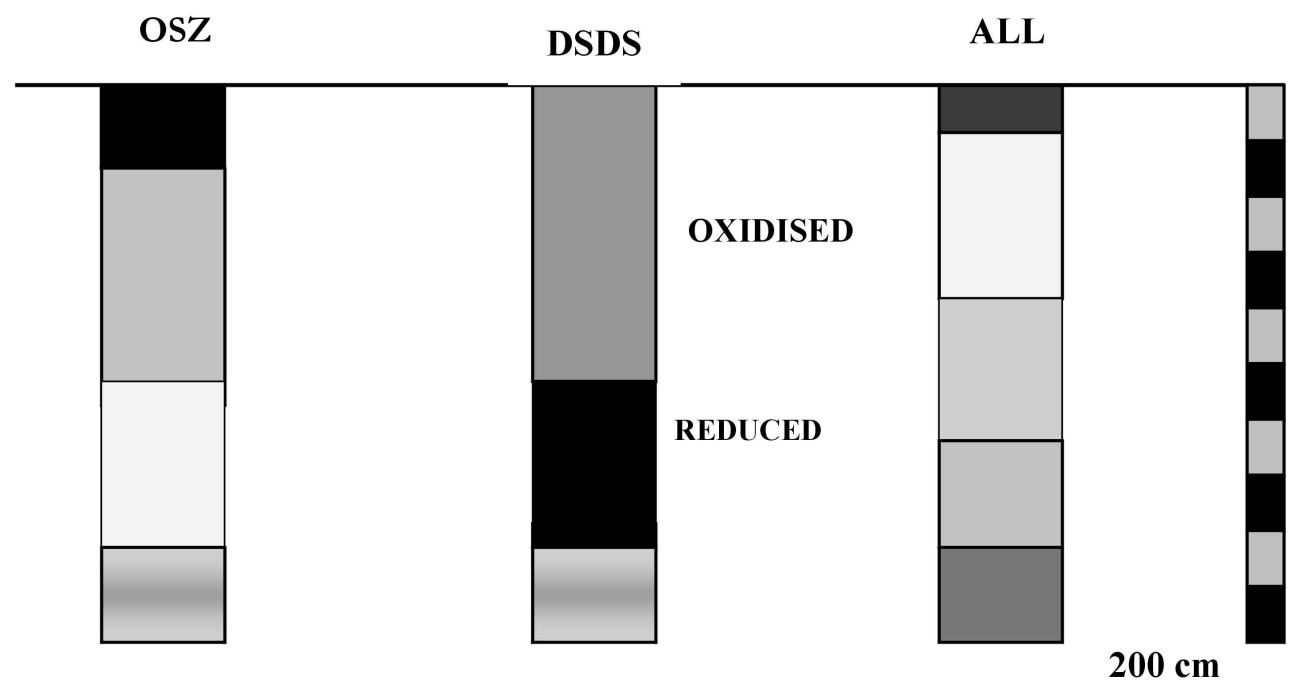

Fig. 1 


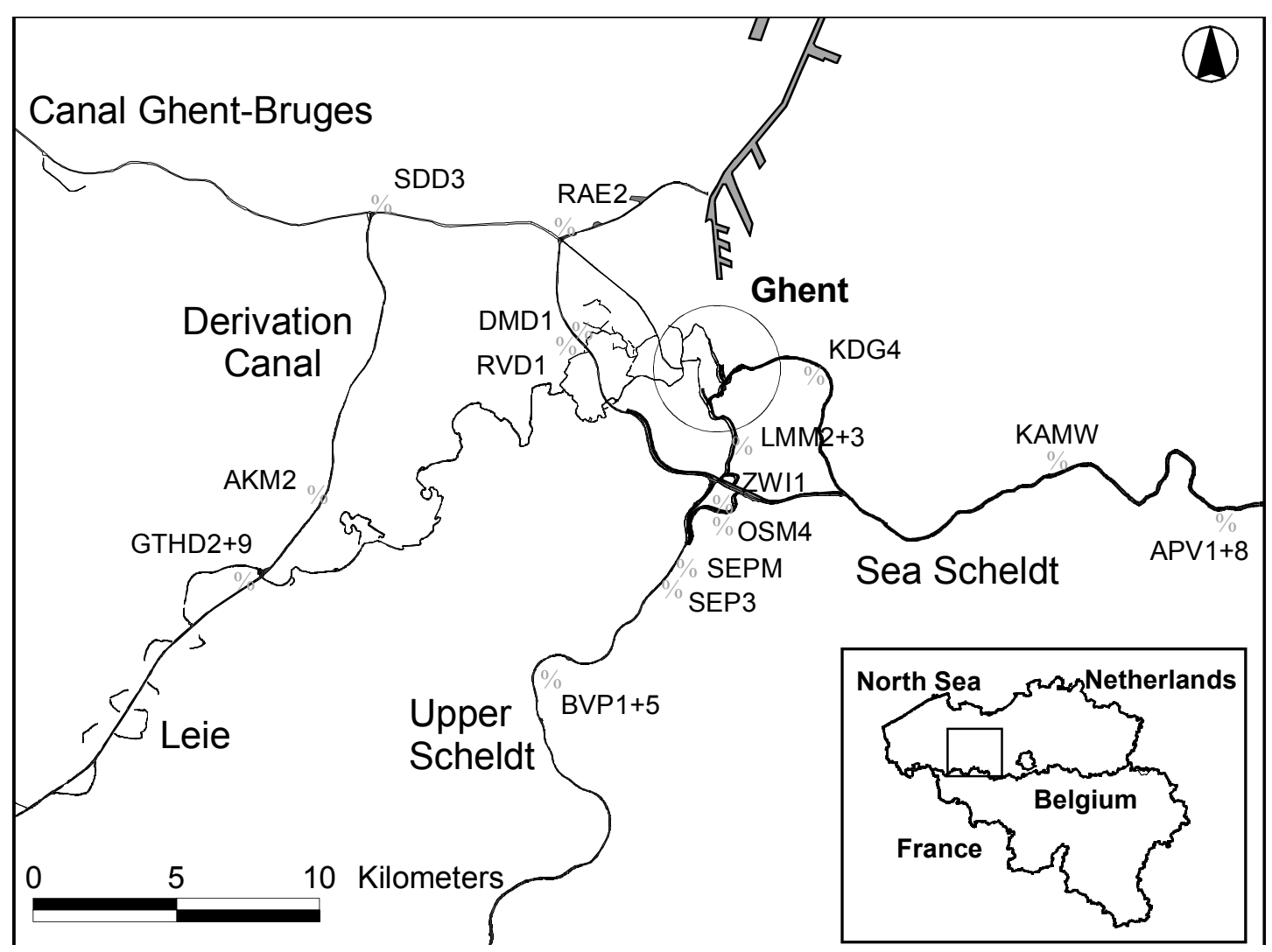

Fig. 2 

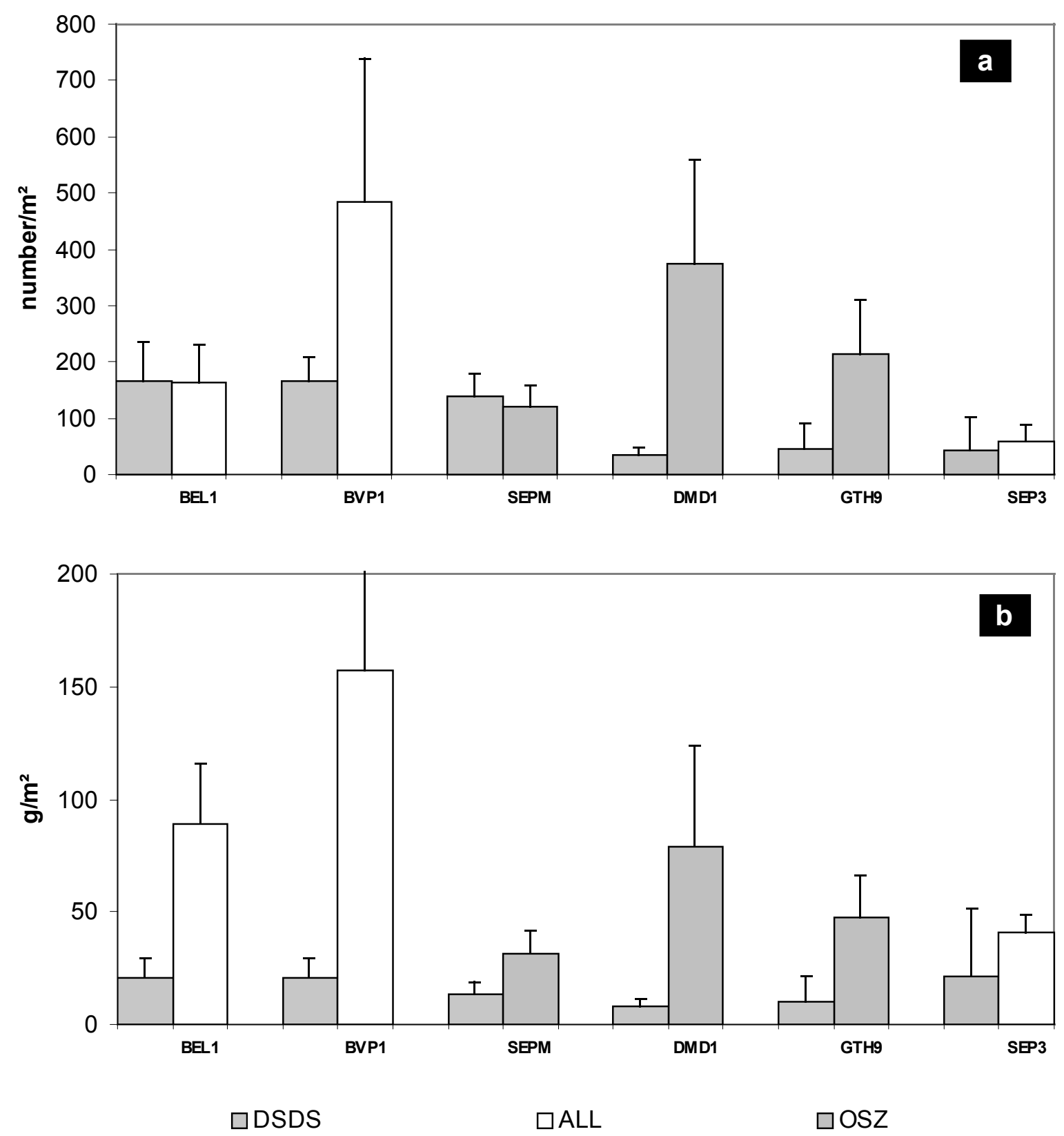

Fig. 3 

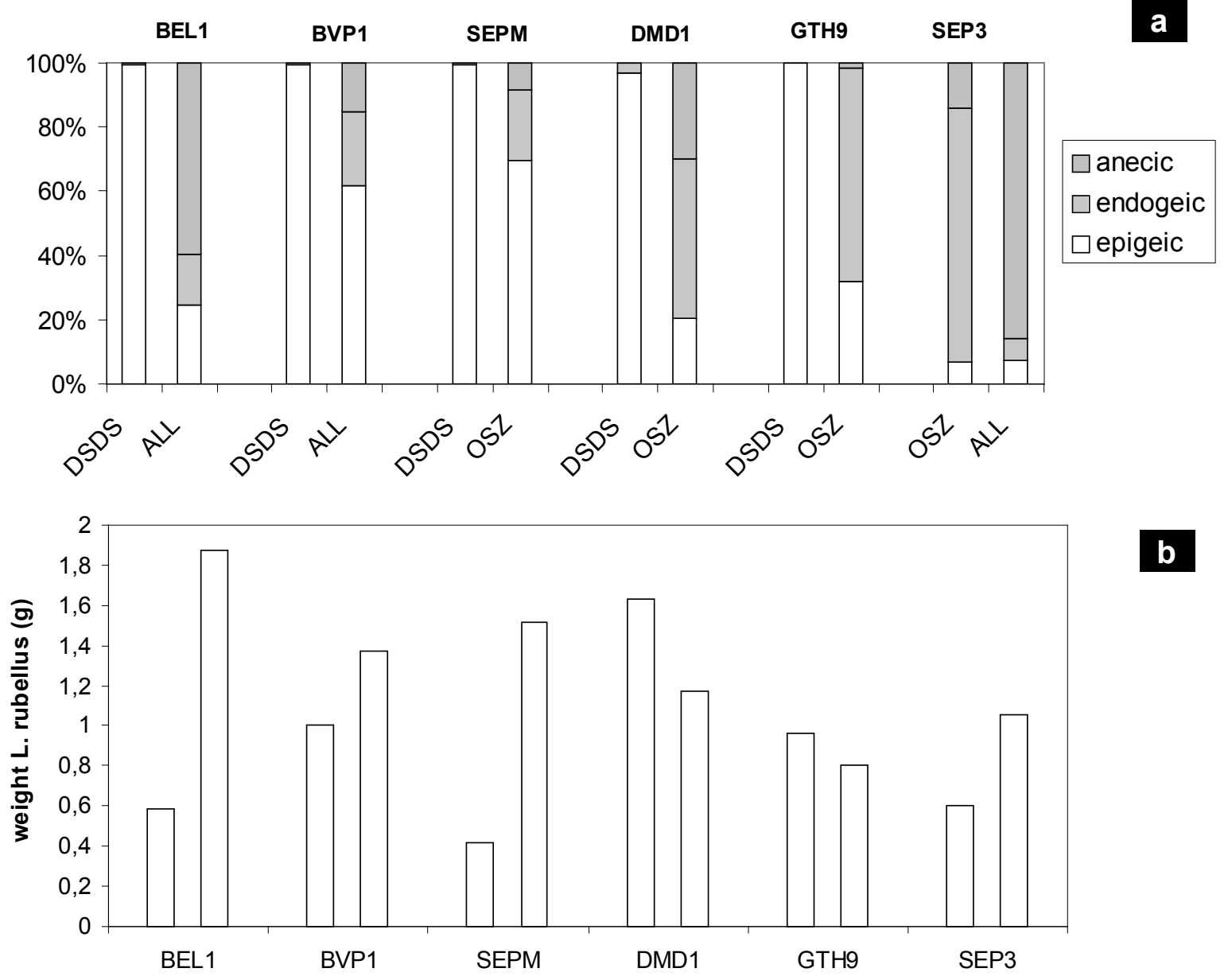

b

Fig. 4 


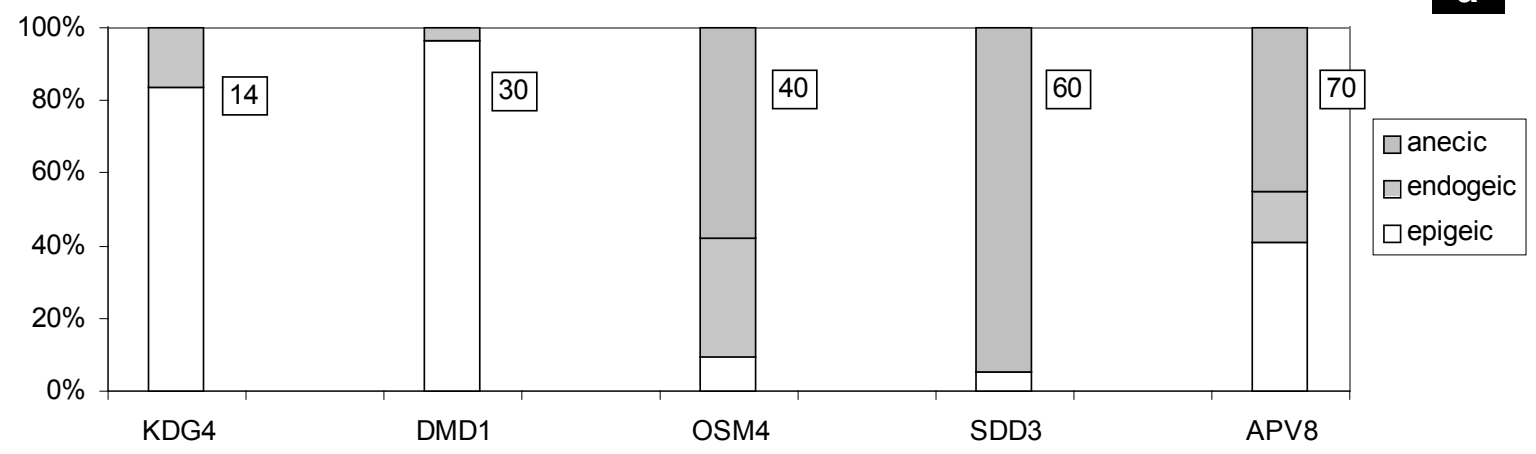

b

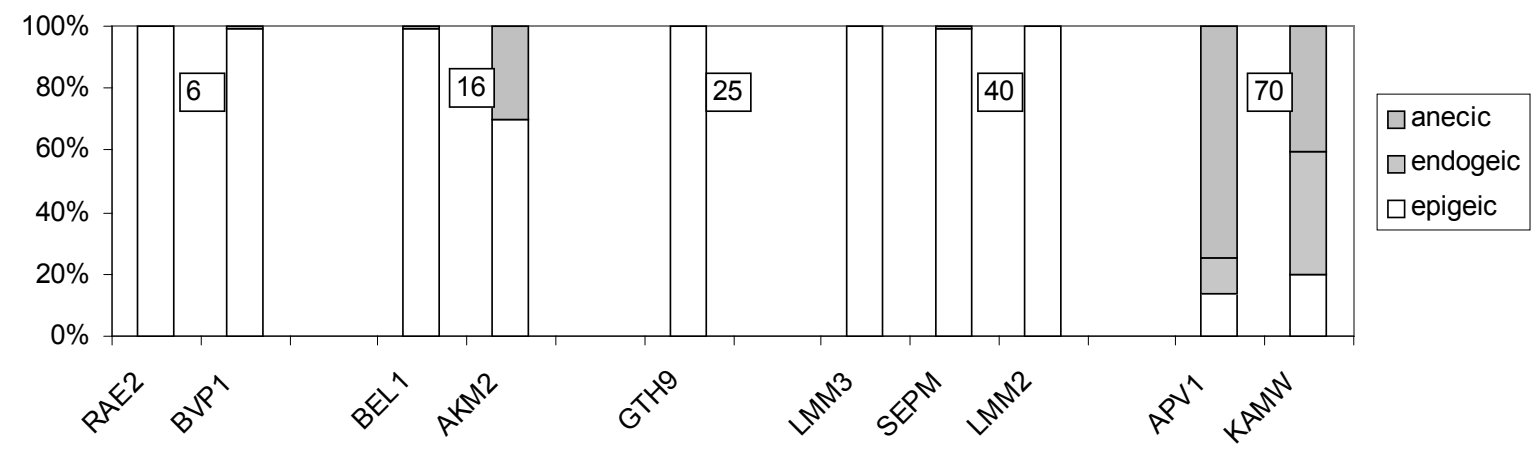

Fig. 5 

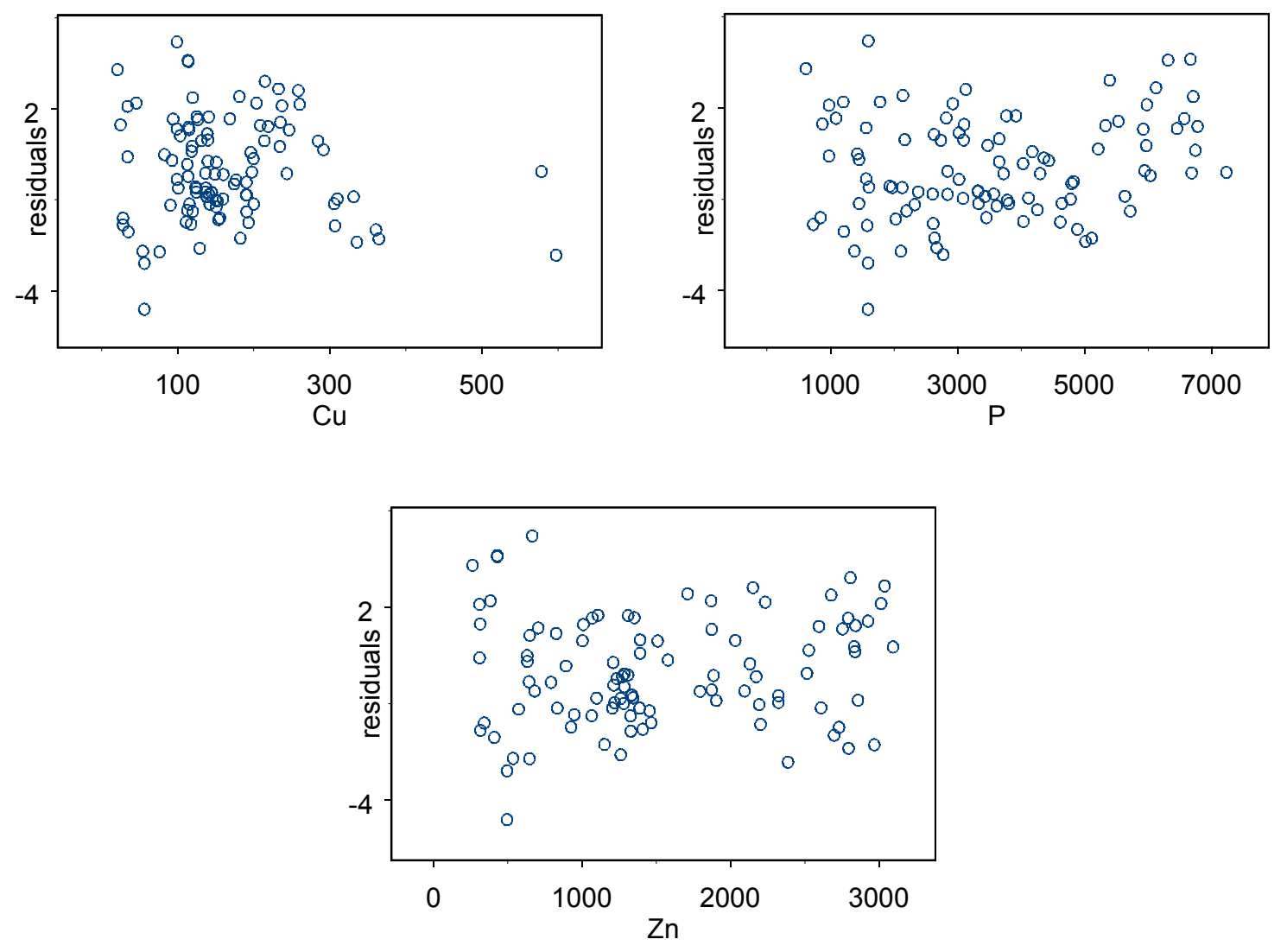

Fig. 6. 